\title{
Faktor-Faktor yang Memengaruhi Tingkat Kriminalitas di Indonesia Tahun 2018
}

\author{
Andrian Dwi Putra ${ }^{1}$, Gracilia Stevi Martha ${ }^{2}$, Muhammad Fikram ${ }^{3}$, Risni Julaeni Yuhan ${ }^{4}$ \\ Politeknik Statistika STIS \\ ${ }^{1}$ andrian.dwi1@gmail.com, ${ }^{4}$ julaenirisni@gmail.com
}

\begin{abstract}
Crime still often occurs easily in daily life in Indonesia. This study aims to determine factors that influence the level of crime in Indonesia in 2018 and the magnitude of the influence of each factor. The data used in this study are secondary data obtained from the Statistics Indonesia (BPS). The method used in this study is path analysis, and the variables used are population, education, unemployment rate, poverty rate, and crime. As a result, population and poverty influenced crime while education influenced poverty significantly.
\end{abstract}

Keywords: crime, path coefficient, path analysis

\section{Pendahuluan}

Pada era globalisasi, dinamika pertumbuhan budaya dan pesatnya perkembangan ilmu pengetahuan dan teknologi, melahirkan persaingan dalam berbagai hal dalam kehidupan manusia, seperti ideologi, sosial, ekonomi, seni, etika, maupun moral. Banyak perubahan yang terjadi pada nilai-nilai yang terkandung didalamnya, seperti materialisme, hedonisme dan lain sebagainya. Hal ini juga mengakibatkan perubahan nilai yang terdapat dalam kemasyarakatan. Perubahan tersebut juga berdampak pada perilaku manusia. Perubahan positif tentu saja sangat menguntungkan masyarakat, tetapi perubahan negatif dapat menyebabkan keresahan dalam kehidupan masyarakat sebagai akibat manusia yang berperilaku negatif, seperti melakukan tindakan kejahatan.

Tindak kejahatan atau krimininalitas di Indonesia marak terjadi. Namun, pemerintah cukup tanggap dalam menyikapi tindak kejahatan di masyarakat. Hal ini ditunjukkan dengan menurunnya tingkat kejahatan (crime rate) di Indonesia periode tahun 2016-2018. Berdasarkan data dari Badan Pusat Statistik, persentase penduduk yang menjadi korban kejahatan di Indonesia selama periode 2016-2018 cenderung fluktuatif, terjadi perubahan menurun sebesar 0,14 persen dari tahun 2016 menuju tahun 2017, dan meningkat kembali menjadi 1,11 persen pada tahun 2018. Hal ini juga diikuti dengan meningkatnya jumlah desa/kelurahan yang menjadi ajang konflik desa selama periode tahun 2011-2018. 
Kejahatan masih menjadi ancaman terbesar bagi rasa aman manusia untuk berkehidupan dalam perubahan-perubahan yang terjadi pada nilai-nilai kemasyarakatan. Rasa aman juga merupakan salah satu hak asasi manusia, sehingga baik pemerintah maupun masyarakat itu sendiri harus saling berkerja sama untuk mengurangi jumlah kejahatan di Indonesia. Oleh karena itu, penulis tertarik untuk melakukan penelitian mengenai faktor-faktor yang mempengaruhi jumlah kejahatan di Indonesia tahun 2018.

Menurut Moeliono dalam Dirdjosisworo [1] kejahatan adalah perbuatan pelanggaran norma hukum yang ditafsirkan atau patut ditafsirkan masyarakat sebagai perbuatan yang merugikan sehingga tidak boleh dibiarkan. Adapun faktor-faktor yang mempengaruhi kriminalitas dapat berasal dari berbagai macam bidang kehidupan manusia.

Penelitian sebelumnya yang terkait faktor yang memengaruhi jumlah tingkat kriminalitas di Indonesia, akan digunakan analisis jalur (path analysis) terhadap tingkat kejahatan (crime rate) di Indonesia. Menurut Muhidin dan Abdurahman [2], analisis jalur (path analysis) adalah alat analisis statistik yang digunakan untuk menganalisis pola hubungan kausal antar variabel dengan tujuan untuk mengetahui pengaruh langsung dan tidak langsung, baik secara serempak maupun secara sendiri-sendiri beberapa variabel penyebab terhadap sebuah variabel akibat. Tujuan dari penelitian ini adalah untuk mengetahui faktor-faktor yang mempengaruhi tingkat kriminalitas di Indonesia tahun 2018 dan besarnya pengaruh dari masing-masing faktor.

\section{Landasan Teori}

2.1. Kriminalitas. Kriminalitas merupakan segala macam bentuk tindakan dan perbuatan yang merugikan secara ekonomis dan psikologis yang melanggar hukum yang berlaku dalam negara Indonesia serta norma-norma sosial dan agama. Dapat diartikan bahwa, tindak kriminalitas adalah segala sesuatu perbuatan yang melanggar hukum dan melanggar norma-norma sosial, sehingga masyarakat menentangnya [3].

2.2. Faktor yang Mempengaruhi Terjadinya Kriminalitas. Pada dasarnya setiap individu akan dipengaruhi oleh beberapa faktor baik intern maupun ekstern yang dapat menyebabkan seseorang melakukan tindakan kriminal [4]. Faktor tersebut diantaranya faktor internal yang meliputi faktor kebutuhan ekonomi yang mendesak, faktor ketanagakerjaan (pengangguran atau memiliki pekerjaan), dan faktor taraf kesejahteraan. 
Faktor eksternal meliputi faktor pendidikan, dan faktor pergaulan atau pengaruh lingkungan.

Menurut Handayani [5], jumlah penduduk yang tinggi pada suatu daerah dapat dikaitikan dengan angka kejahatan yang tinggi pada daerah tersebut. Hal ini juga diikuti dengan angka Penyandang Masalah Kesejahteraan Sosial (PMKS) yang tinggi. Tak jarang PMKS menjadi pelaku kejahatan jika tidak diatasi dengan baik.

Pengangguran adalah jumlah tenaga kerja dalam perekonomian yang aktif mencari pekerjaan, tetapi belum memperolehnya. Pengangguran dapat menjadi dampak buruk bagi perekonomian individu maupun masyarakat [6]. Sejalan dengan hal tersebut, penelitian Dermawanti [7] di Kabupaten Batang menyatakan bahwa faktor pengangguran memiliki pengaruh terbesar terhadap kriminalitas. Tingginya angka pengangguran juga akan mengakibatkan peningkatan angka kemiskinan. Menurut Bank Dunia salah satu penyebab kemiskinan adalah karena kurangnya pendapatan dan aset untuk memenuhi kebutuhan dasar seperti makanan, pakaian, perumahan dan tingkat kesehatan dan pendidikan yang dapat diterima.

Pendidikan masih menjadi salah satu sarana penting untuk meningkatkan sumber daya manusia. Menurut Lochner [8], partisipasi sekolah yang tinggi pada masyarakat dapat menurunkan tingkat kriminalitas karena waktu mereka akan habis untuk bersekolah.

2.3. Analisis Jalur. Analisis jalur adalah suatu teknik untuk menganalisis hubungan sebab akibat yang terjadi pada regresi berganda jika variabel bebasnya mempengaruhi variabel tergantung tidak hanya secara langsung tetapi juga secara tidak langsung [9].

Istilah-istilah yang digunakan dalam analisis jalur adalah sebagai berikut:

1. Model jalur adalah suatu diagram yang menghubungkan antara variabel bebas, perantara dan tergantung yang ditunjukkan dengan menggunakan anak panah.

2. Variabel exogenous merupakan semua variabel yang dalam diagram tidak ada anak-anak panah yang menuju ke arahnya.

3. Variabel endogenous merupakan variabel yang mempunyai anak panah yang menuju ke arahnya.

4. Koefisien jalur $(\rho)$ adalah koefisien regresi standar yang menunjukkan pengaruh langsung dari suatu variabel bebas terhadap variabel tergantung dalam suatu model jalur tertentu. 
5. Direct Effect (DE) adalah pengaruh langsung yang dapat dilihat dari koefisien jalur dari variabel eksogen ke variabel endogen.

6. Indirect Effect (IE) adalah urutan jalur melalui satu atau lebih variabel perantara.

7. Gangguan atau residue mencerminkan adanya varian yang tidak dapat diterangkan atau pengaruh dari semua variabel yang tidak terukur ditambah dengan kesalahan pengukuran yang merefleksikan penyebab variabilitas yang tidak diketahui pada hasil analisis.

Asumsi analisis jalur menurut Dillon dan Goldstein [10]:

1. Hubungan antar variabel endogen dengan variabel eksogen bersifat linier, aditif, dan sebab akibat.

2. Error tidak saling berkorelasi satu sama lain.

3. Hanya terdapat hubungan kausal satu arah dalam model, yaitu model rekursif.

4. Variabel endogen minimal terukur dalam skala interval.

5. Variabel yang diamati diasumsikan diukur tanpa kesalahan.

6. Model yang di analisis diidentifikasi dengan benar berdasarkan teori dan konsep yang relevan.

\section{Metodologi}

3.1. Sumber Data. Data yang digunakan dalam penelitian adalah data sekunder yang berasal dari Badan Pusat Statistik, dengan observasi berupa seluruh provinsi yang ada di Indonesia. Data didapatkan dari publikasi dan website Badan Pusat Statistik [11,12].

3.2. Variabel Penelitian. Variabel yang digunakan dalam penelitian ini adalah kriminalitas yang dilihat dari crime rate menurut provinsi tahun 2018, jumlah penduduk, pendidikan yang dilihat dari rata-rata lama sekolah, pengangguran, dan kemiskinan yang dilihat dari persentase penduduk miskin menurut provinsi tahun 2018 [13].

Variabel eksogen dalam penelitian ini adalah jumlah penduduk, pendidikan, dan pengangguran. Variabel endogen yang digunakan adalah kriminalitas dan kemiskinan dimana kemiskinan merupakan variabel mediator.

3.3. Metode Analisis. Langkah menghitung dan menguji koefisien jalur dengan pendekatan korelasi sederhana :

1. Membentuk model jalur

2. Menghitung matriks korelasi 


$$
R=\left|\begin{array}{cccc}
1 & r_{12} & \cdots & r_{1 k} \\
r_{21} & 1 & \cdots & r_{2 k} \\
\vdots & \vdots & \vdots & \vdots \\
r_{k 1} & r_{k 2} & \cdots & 1
\end{array}\right|
$$

3. Menentukan invers matriks eksogen

$$
R^{-1}=\left|\begin{array}{cccc}
C_{11} & C_{12} & \cdots & C_{1 k} \\
C_{21} & C_{22} & \cdots & C_{2 k} \\
\vdots & \vdots & \vdots & \vdots \\
C_{k 1} & C_{k 2} & \cdots & C_{k k}
\end{array}\right|
$$

4. Menghitung semua koefisien jalur

$$
\left|\begin{array}{c}
p X_{u} X_{1} \\
p X_{u} X_{2} \\
\cdots \\
p X_{u} X_{k}
\end{array}\right|=\left|\begin{array}{cccc}
C_{11} & C_{12} & \cdots & C_{1 k} \\
C_{21} & C_{22} & \cdots & C_{2 k} \\
\vdots & \vdots & \vdots & \vdots \\
C_{k 1} & C_{k 2} & \cdots & C_{k k}
\end{array}\right|\left|\begin{array}{c}
r X_{u} X_{1} \\
r X_{u} X_{2} \\
\cdots \\
r X_{u} X_{k}
\end{array}\right|
$$

5. Menentukan harga koefisien determinasi ganda

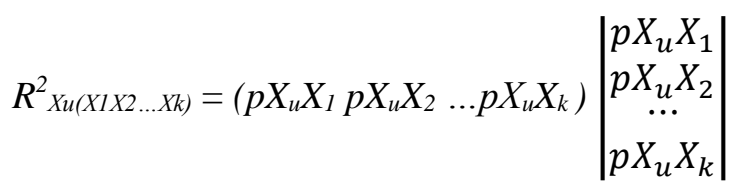

6. Pengujian Koefisien Jalur

Hipotesis:

$\mathrm{H}_{0}: p=O$ (Tidak terdapat pengaruh variabel eksogen terhadap variabel endogen)

$\mathrm{H}_{1}: p \neq 0$ (Terdapat pengaruh variabel eksogen terhadap variabel endogen)

Statistik Uji:

$$
t=\frac{p X_{u} X_{1}}{\sqrt{\left[1-R_{X_{u}\left(X_{1} X_{2} \ldots X_{k}\right)}^{2}\right] C_{i i} /(n-k-1)}}
$$

dengan: $i=1,2, \ldots, k$

$k$ : banyak variabel eksogen dalam sub-struktur yang sedang diuji

keputusan:

$H_{0}$ ditolak jika $t_{\text {hitung }}>t_{\text {tabel }(\alpha 2, n-k-1)}$ atau nilai signifikansi $<\alpha$

7. Perhitungan pengaruh tak langsung dan pengaruh total. 


\section{Hasil dan Pembahasan}

4.1. Pembentukan Model Jalur. Berdasarkan uraian dalam tinjauan pustaka dan hasil penelitian oleh Harlik dkk. [14] diketahui bahwa tingkat kemiskinan $\left(X_{4}\right)$ di pengaruhi oleh jumlah penduduk $\left(X_{1}\right)$, pendidikan $\left(X_{2}\right)$, dan pengangguran $\left(X_{3}\right)$. Sedangkan kriminalitas $\left(X_{5}\right)$ di pengaruhi oleh jumlah penduduk $\left(X_{1}\right)$, pendidikan $\left(X_{2}\right)$, pengangguran $\left(X_{3}\right)$, dan tingkat kemiskinan $\left(X_{4}\right)$. Model struktural yang terbentuk adalah

$$
\begin{gathered}
X_{4}=p_{41} X_{1}+p_{42} X_{2}+p_{43} X_{3}+e_{4} \\
X_{5}=p_{51} X_{1}+p_{52} X_{2}+p_{53} X_{3}+p_{54} X_{4}+e_{5}
\end{gathered}
$$

dan diagram jalur yang dihasilkan dapat dilihat pada Gambar 1 .

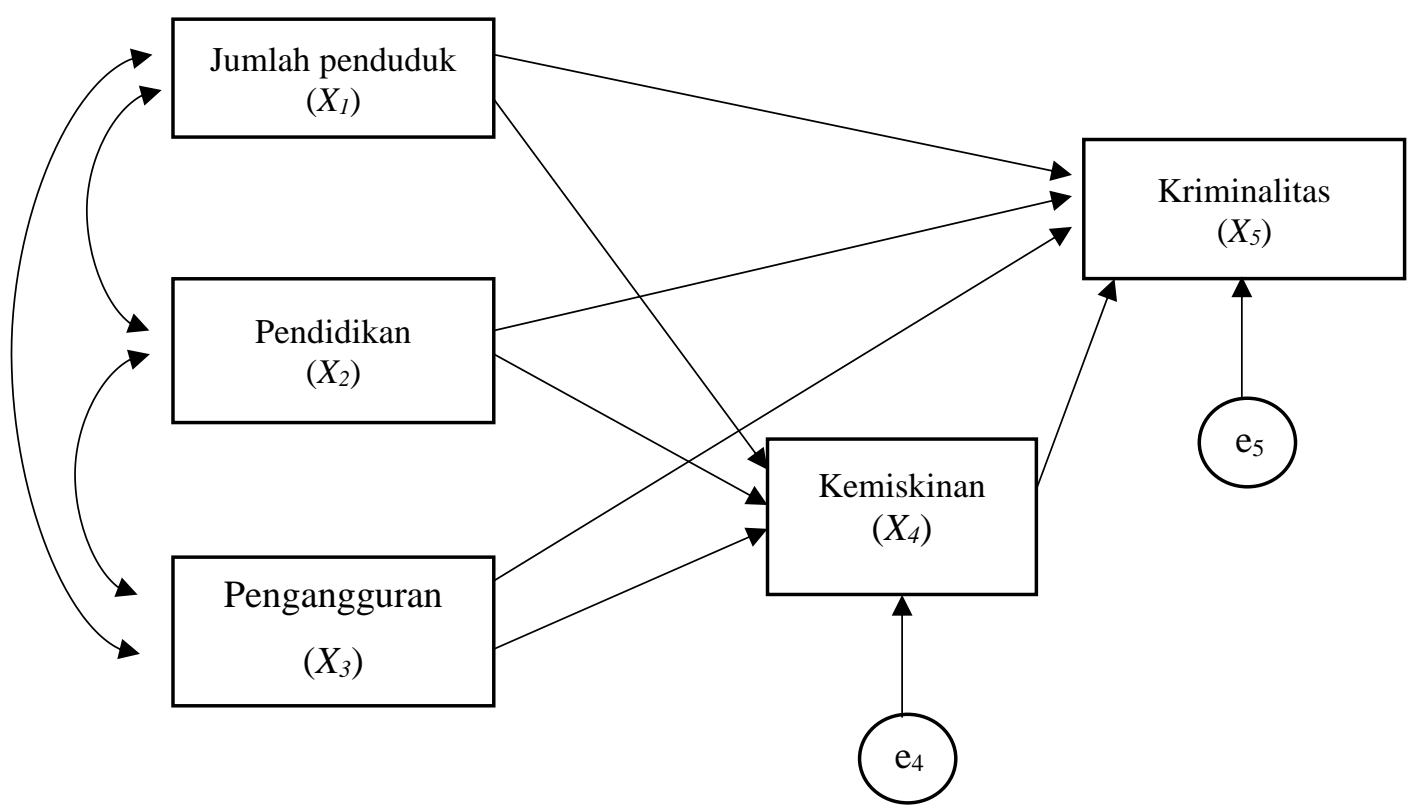

Gambar 1. Diagram Jalur Model

4.2. Perhitungan Koefisien Jalur. Hasil penghitungan dari 5 variabel yang digunakan dalam penelitian ini, dihasilkan matriks korelasi:

$$
R=\left|\begin{array}{ccccc}
1 & -0,167 & 0,251 & -0,119 & -0,393 \\
-0,167 & 1 & 0,518 & -0,376 & 0,186 \\
0,251 & 0,518 & 1 & -0,213 & 0,103 \\
-0,119 & -0,376 & -0,213 & 1 & 0,331 \\
-0,393 & 0,186 & 0,103 & 0,331 & 1
\end{array}\right|
$$

Hubungan kemiskinan dengan jumlah penduduk, pendidikan dan pengangguran adalah

$$
\left|\begin{array}{l}
p_{41} \\
p_{42} \\
p_{43}
\end{array}\right|=R_{3}^{-1}\left|\begin{array}{l}
r X_{4} X_{1} \\
r X_{4} X_{2} \\
r X_{4} X_{3}
\end{array}\right|=\left|\begin{array}{c}
-0,213 \\
-0,449 \\
0,073
\end{array}\right|
$$


Berdasarkan hasil perhitungan koefisien jalur model struktural kemiskinan $\left(X_{4}\right)$ didapatkan pengaruh langsung dari variabel jumlah penduduk sebesar $-0,213$, variabel pendidikan sebesar -0,449, dan variabel pengangguran sebesar 0,073. Hasil uji signifikansi menunjukkan nilai- $p$ untuk pengaruh kemiskinan oleh variabel jumlah penduduk sebesar 0,255 (nilai- $p \geq 0,05$ ), variabel pendidikan sebesar 0,038 (nilai- $p<$ 0,05 ), dan variabel pengangguran sebesar 0,732 (nilai- $p \geq 0,05$ ). Dapat disimpulkan bahwa variabel pendidikan $\left(X_{2}\right)$ signifikan mempengaruhi kemiskinan $\left(X_{4}\right)$, sedangkan variabel jumlah penduduk $\left(X_{l}\right)$ dan pengangguran $\left(X_{3}\right)$ tidak signifikan mempengaruhi kemiskinan $\left(X_{4}\right)$ di Indonesia tahun 2018. Model yang dihasilkan memiliki nilai $R$-Square sebesar 0,178 yang artinya bahwa variabel eksogen (variabel bebas) dalam penelitian dapat menjelaskan variabel kemiskinan sebanyak 17,8\% ,dan 82,2\% lainnya dijelaskan oleh variabel lainnya, serta dihasilkan variabel sisanya $\left(e_{4}\right)$ sebesar 0,907 .

Hubungan kriminalitas dengan jumlah penduduk, pendidikan, pengangguran, dan kemiskinan dinyatakan dengan

$$
\left|\begin{array}{l}
p_{51} \\
p_{52} \\
p_{53} \\
p_{54}
\end{array}\right|=R_{4}^{-1}\left|\begin{array}{l}
r X_{5} X_{1} \\
r X_{5} X_{2} \\
r X_{5} X_{3} \\
r X_{5} X_{4}
\end{array}\right|=\left|\begin{array}{c}
-0,363 \\
0,176 \\
0,187 \\
0,394
\end{array}\right|
$$

Berdasarkan hasil perhitungan koefisien jalur model struktural kriminalitas $\left(X_{5}\right)$ didapatkan pengaruh langsung dari variabel jumlah penduduk sebesar $-0,363$, variabel pendidikan sebesar 0,176 , variabel pengangguran sebesar 0,187 , dan variabel kemiskinan sebesar 0,394. Hasil uji signifikansi menunjukkan nilai- $p$ untuk pengaruh kriminalitas oleh variabel jumlah penduduk sebesar 0,044 (nilai- $p<0,05$ ), variabel pendidikan sebesar 0,398 (nilai- $p \geq 0,05$ ), variabel pengangguran sebesar 0,345 (nilai- $p \geq 0,05$ ), dan variabel kemiskinan sebesar 0,026 (nilai- $p<0,05$ ). Sehingga dapat disimpulkan bahwa variabel jumlah penduduk $\left(X_{1}\right)$ dan kemiskinan $\left(X_{4}\right)$ signifikan mempengaruhi kriminalitas $\left(X_{5}\right)$, sedangkan variabel pendidikan $\left(X_{2}\right)$ dan pengangguran $\left(X_{3}\right)$ tidak signifikan mempengaruhi kriminalitas $\left(X_{5}\right)$ di Indonesia tahun 2018. Model yang dihasilkan memiliki nilai $R$-Square sebesar 0,325 yang artinya bahwa variabel eksogen (variabel bebas) dalam penelitian dapat menjelaskan variabel kriminalitas sebanyak 32,5\% ,dan $77,5 \%$ lainnya dijelaskan oleh variabel lainnya, serta dihasilkan variabel sisanya $\left(e_{5}\right)$ sebesar 0,822 .

4.3. Pengaruh Tidak Langsung dan Pengaruh Total. Tabel 1 menunjukkan pengaruh langsung, pengaruh tidak langsung, dan pengaruh total variabel jumlah penduduk $\left(X_{I}\right)$, pendidikan $\left(X_{2}\right)$, pengangguran $\left(X_{3}\right)$, dan kemiskinan $\left(X_{4}\right)$ terhadap 
variabel kriminalitas $\left(X_{5}\right)$. Berdasarkan model yang terbentuk, variabel kemiskinan $\left(X_{4}\right)$ hanya memiliki pengaruh langsung terhadap kriminalitas $\left(X_{5}\right)$.

Tabel 1. Koefisien Jalur Tidak Langsung Dan Total

\begin{tabular}{cccc}
\hline koefisien jalur & pengaruh langsung & pengaruh tidak langsung & $\begin{array}{c}\text { pengaruh } \\
\text { total }\end{array}$ \\
\hline$(1)$ & $(2)$ & $(3)$ & $(4)$ \\
$p_{51}$ & $-0,363$ & $-0,143$ & $-0,506$ \\
$p_{52}$ & 0,176 & 0,069 & 0,245 \\
$p_{53}$ & 0,187 & 0,074 & 0,261 \\
$p_{54}$ & 0,394 & & 0,394 \\
\hline
\end{tabular}

Dapat diketahui juga bahwa kemiskinan mempunyai pengaruh total paling besar terhadap kriminalitas yang terjadi yaitu sebesar 0,394. Pendidikan memiliki pengaruh yang paling kecil terhadap tingkat kriminalitas di Indonesia dengan pengaruh langsung 0,176 dan pengaruh tidak langsung 0,069 .

\section{Kesimpulan}

Berdasarkan hasil dan pembahasan dapat ditarik kesimpulan bahwa jumlah penduduk dan kemiskinan secara parsial signifikan memengaruhi tingkat kriminalitas di Indonesia, sedangkan variabel pendidikan dan pengangguran secara parsial tidak signifikan berpengaruh terhadap tingkat kriminalitas di Indonesia pada 2018. Berdasarkan model yang dihasilkan, didapatkan bahwa nilai $R$-Square yang masih rendah, sehingga pada penelitian selanjutnya diperlukan modifikasi pada model atau dengan menambah variabel penjelas, sehingga dapat menunjukkan hasil yang lebih baik.

\section{Daftar Pustaka}

[1] Dirdjosisworo, S. Doktrin-Doktrin Kriminologi. Alumni Bandung. Bandung. 1969.

[2] Muhidin, S. A., dan Abdurahman, M. Analisis korelasi, regresi, dan jalur dalam penelitian. Pustaka Setia. Bandung. 2007.

[3] Kartono, K. Patologi Sosial, jilid I. PT Raja Grafindo Persada. Jakarta. 1999.

[4] Kansil, C. S. T., dan Kansil, C. Hukum Pidana Untuk Perguruan Tinggi. PT Sinar Grafika. Jakarta. 1994.

[5] Handayani, R. Analisis Dampak Kependudukan terhadap Tingkat Kriminalitas di Provinsi Banten. Jurnal Administrasi Publik, 8(2). Banten. 2017.

[6] Sukirno, S. Makroekonomi Teori Pengantar Edisi Ketiga. Raja Grafindo Persada. Jakarta. 2004.

[7] Dermawanti, D., Hoyyi, A., dan Rusgiyono, A. Faktor-Faktor yang Mempengaruhi Kriminalitas di Kabupaten Batang Tahun 2013 dengan Analisis Jalur. Jurnal Gaussian, 4(2), 247-256. Semarang. 2015. 
[8] Lochner, L. Individual perceptions of the criminal justice system. American Economic Review, 97(1), 444-460. 2007.

[9] Sarwono. Analisis Jalur Untuk Riset Bisnis dengan SPSS. Andi Offset. Yogyakarta. 2007.

[10] Dilon, W. R., dan Goldstein, M. Multivariate Analyses. John Willey \& Sons. New York. 1984

[11] Badan Pusat Statistik RI. Statistik Kriminal 2018. Jakarta. Badan Pusat Statistik. 2018.

[12] Badan Pusat Statistik RI. Statistik Kriminal 2019. Jakarta: Badan Pusat Statistik. 2019.

[13] Irhamni, I. Pengaruh Jumlah Penduduk, Pengangguran, dan Pengeluaran Pemerintah Terhadap Kemiskinan di Indonesia Tahun 1986-2015. Jurnal Pendidikan dan Ekonomi, 7(1), 88-97. Yogyakarta. 2018.

[14] Harlik, H., Amir, A., dan Hardiani, H. Faktor-faktor yang mempengaruhi kemiskinan dan pengangguran di Kota Jambi. Jurnal Perspektif Pembiayaan dan Pembangunan Daerah, 1(2), 109-120. Jambi. 2013. 